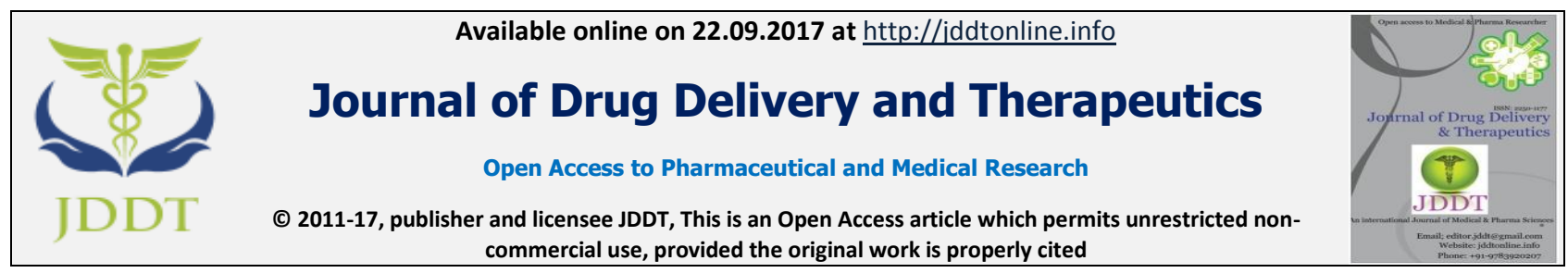

Open $\odot$ Access

Research Article

\title{
FORMULATION AND EVALUATION OF ORAL FAST DISSOLVING TABLET OF ONDANSETRON HYDROCHLORIDE BY COPROCESS EXCIPIENTS
}

\author{
Shaikh Siraj Nawaj*, Shaikh Heena Kausar, G. J. Khan, Tajammul Khan \\ Department of Pharmaceutics, Ali-Allana College of Pharmacy Akkalkuwa, Nandurbar, Maharashtra, India
}

\section{ABSTRACT}

Recent development in fast disintegrating technology mainly works to improve the quality of these delicate dosage forms without affecting their integrity. Current investigations deal with the formulation of fast dissolving tablet of Ondansetron $\mathrm{HCl}$ with the effect of different co-processed excipients by using ball mill that disintegrates in oral cavity on contact with saliva \& thereby improve therapeutic efficacy because the mannitol was stick to dies and punch therefore ball mill is used to prepare co ground mixtures of crospovidone and mannitol to improve the compatibility and stability of product. The Fast disintegrating tablets of Ondansetron $\mathrm{HCl}$ were prepared by direct compression method using different synthetic superdisintegrant such as Crospovidone, and natural superdisintegranst such as Karaya gum and Fenugreek gum in different concentration. The FTIR, DSC analysis revealed that the Betacyclodextrin and superdisintegrants used were compatible with Ondansetron $\mathrm{HCl}$. A complex of Betacyclodextrin and Ondansetron $\mathrm{HCl}$ was successfully formed in 1:2 ratios. Disintegration time decrease with increase in the concentration o superdisintegrant. Among all formulation, containing Karaya Gum as superdisintegrants is fulfilling all the parameters satisfactorily. In vitro release studies that almost $98.88 \%$ of the drug was released from all the formulation were within 15 minutes. Best Formulation F6 showed faster drug release within 7 minutes in comparison to other formulation. ThE result shows that Coprocessing of excipients is the most suitable approach for formulation of Fast dissolving tablet.

Keywords: Coprocess, Fast disintegrating tablets, Ball mill, Disintegration time, Mannitol etc.

Article Info: Received 20 July, 2017; Review Completed 14 Sep, 2017; Accepted 14 Sep, 2017; Available online 22 Sep, 2017

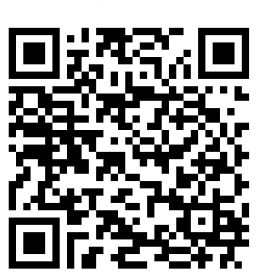

\section{Cite this article as:}

Siraj SN, Kausar SH, Khan GJ, Khan T, Formulation and evaluation of oral fast dissolving tablet of ondansetron hydrochloride by coprocess excipients, Journal of Drug Delivery and Therapeutics. 2017; 7(5):102-108

DOI: http://dx.doi.org/10.22270/jddt.v7i5.1498

*Address for Correspondence

Shaikh Siraj Nawaj, Head Department of Pharmaceutics, Ali-Allana College of Pharmacy Akkalkuwa, Nandurbar, Maharashtra, India. E-mail: Sirajsk1234@gmail.com

\section{INTRODUCTION}

United States Food and drug administration defined fast disintegrating tablet as "a solid dosage form containing medicinal substance or active ingredient which disintegrate fast usually within a few seconds when placed upon the tongue." FDTs differ from traditional tablets as they are designed to be dissolved on the tongue rather than swallowed whole. Fast disintegrating tablets are also known as mouth disintegrating tablets, melt-in mouth tablets, Orodispersible tablets, porous tablets, quick dissolving tablets, fast dissolving tablets. ${ }^{1}$ According to US Food and Drug Administration 2008 publications of guidance are: FDTs should have an In vitro disintegrating time of approximately $30 \mathrm{sec}$ or less. $^{2}$ Generally, the FDT tablet weight should not exceed $500 \mathrm{mg}$, although the combine influence of stable weight, size and component solubility all factor into the acceptability of an ODT for both patients and regulators. Recent advances in novel drug delivery system aim to enhance safety and toxicity of drug molecules by formulating a convenient dosage form for administration and to achieve better patient compliance. ${ }^{4}$ One such approach led to development of fast dissolving tablets. Fast dissolving drug-delivery systems were first developed in the late $1970 \mathrm{~s}$ as an alternative to conventional dosage forms for paediatric and geriatric patient. Traditional tablets and capsules administered 
with an 8-oz. glass of water may be inconvenient or impractical for some patients who experience difficulties in swallowing traditional oral solid-dosage forms. These tablets are designed to dissolve or disintegrate rapidly in the saliva generally less than 60 seconds ${ }^{5}$

\section{Coprocessed Excipients ${ }^{6}$}

Co-processing is based on the novel concept of two or more excipients interacting at the sub particle level, the objective of which is to provide a synergy of functionality improvement as well as masking the undesirable properties of individual. Co-processing excipients leads to the formulation of excipient granules with superior properties compared with physical mixtures of components or individual components. The resulting engineered excipients are commonly known as "coprocessed," "high functionality," "multifunctional," "high functionality," "performance" excipients.

\section{Significance of the co-processed excipients}

1. Enhancement in flow properties

2. Absence of chemical change

3. Better dilution potential

4. Fill weight variation

5. Reduced lubricant sensitivity

6. Improved compressibility ${ }^{8}$

All coprocessed and modified excipients are playing very important role in the development of easy dosage form. Compared with existing excipients, the improved physical, mechanical, and chemical properties of such excipients have helped in solving formulation problems such as flow ability, compressibility, hygroscopicity, palatability, dissolution, disintegration, sticking, and dust generation. There is need to develop new specially designed equipment for evaluations of coprocessed excipients \& Coprocessed excipients have yet to find their way into official monographs, also we can explore coprocessed excipients in various drug deliveries. ${ }^{9,10}$

\section{MATERIALS AND METHOD}

Ondansetron $\mathrm{HCl}$ was obtained as a gift sample Maxheal Pharmaceuticals, MIDC, Nashik Crospovidone, Karaya gum, Fenugreek gum, Sodium bicarbonate, Microcrystalline cellulose, Flavor ,Mannitol, Aspartame ,Mg. stearate, Talc, Beta cyclodextrin. From Research Lab Fine Chem. Ltd. Mumbai.

\section{Methods:}

\section{Preformulation study}

a) Identification and characterization of Ondansetron $\mathrm{HCl}$ b) Determination of Melting point: The melting point of the drug was determined using capillary tube.

c) Calibration Curve in 6.8 Phosphate Buffer:

d) Compatibility Study of Drug and Excipients:

i) FTIR spectrum

ii) DSC

\section{Preparation of drug and BCD complex by kneading method:}

A mixture of Ondansetron $\mathrm{HCl}$ and Betacyclodextrin was ground in a glass container and a minimum amount of water was added. The mixture was kneading for 5 min and dried at $60^{\circ} \mathrm{C}$ in the vacuum oven. After drying inclusion complex of Ondansetron $\mathrm{HCl}$ and $\beta$ cyclodextrin was obtained.

\section{Preparation of coprecessed co-ground mixture for FDTS by using ball mill}

Coground Mixture and FDTs Coground mixtures prepared by using a ball mill. The Coground mixtures were blended with drug, mannitol, and magnesium stearate in a glass bottle using manual shaking. After blending, the mixtures were compressed using a single tableting machine. The purpose of this study was to prepare oral fast disintegrating tablets (OFDTs) by directly compressing a mixture of mannitol and Crospovidone .When the mixture of mannitol and Crospovidone was co-processed by ball mill .To improve the compatibility and their stability during storage. The (OFDTs) without this co-processing, the powder mixture had poor compatibility, and the stability of the tablet was inferior, probably due to the high Hygroscopicity of Crospovidone. The OFDTs containing co-ground mixture of crospovidone/mannitol showed good stability for six months under humid conditions with rapid disintegration and increase hardness of the tablets Tablet stability could not be achieved using a physical mixture of crospovidone/mannitol without including the co-ground process. ${ }^{11,12}$

\section{Formulation of oral fast disintegrating tablets}

The best batch obtained from Kneading method with 1:2 ratio of inclusion complex was prepared by direct compression method containing $12 \mathrm{mg}$ of Ondansetron. Drug + Beta cyclodextrin inclusion complex equivalent to $4 \mathrm{mg}$ of Ondansetron was taken and pass through the \# 40. Diluents, superdisintegrants, sweetener and flavour were passed through \# 40. All above ingredients were mixed and blended properly. Magnesium stearate was passed through \# 40 and mixed properly with above blend. Powdered lubricated blend was compressed into tablet by Rimek, minipress- $2^{\text {nd }}$ DL 09 station tooling machine using, $7 \mathrm{~mm}$ round flat punches. 


\begin{tabular}{|l|c|c|c|c|c|c|c|c|c|}
\hline \multicolumn{1}{|c|}{ Ingredients } & $\begin{array}{l}\text { F1 } \\
(\mathbf{m g})\end{array}$ & $\begin{array}{l}\text { F2 } \\
(\mathbf{m g})\end{array}$ & $\begin{array}{l}\text { F3 } \\
(\mathbf{m g})\end{array}$ & $\begin{array}{l}\text { F4 } \\
(\mathbf{m g})\end{array}$ & $\begin{array}{l}\text { F5 } \\
(\mathbf{m g})\end{array}$ & $\begin{array}{l}\text { F6 } \\
(\mathbf{m g})\end{array}$ & $\begin{array}{l}\text { F7 } \\
(\mathbf{m g})\end{array}$ & $\begin{array}{l}\text { F8 } \\
(\mathbf{m g})\end{array}$ & $\begin{array}{l}\text { F9 } \\
(\mathbf{m g})\end{array}$ \\
\hline $\begin{array}{l}\text { OSH+BCD complex } \\
\text { (equivalent to 4mg Drug) (1:2) }\end{array}$ & $\mathbf{1 2}$ & $\mathbf{1 2}$ & $\mathbf{1 2}$ & $\mathbf{1 2}$ & $\mathbf{1 2}$ & $\mathbf{1 2}$ & $\mathbf{1 2}$ & $\mathbf{1 2}$ & $\mathbf{1 2}$ \\
\hline Fenugreek Gum & $\mathbf{4}$ & $\mathbf{8}$ & $\mathbf{1 0}$ & - & - & - & - & - & - \\
\hline Karaya Gum & - & - & - & $\mathbf{4}$ & $\mathbf{8}$ & $\mathbf{1 0}$ & - & - & - \\
\hline Crospovidone & - & - & - & - & - & - & $\mathbf{4}$ & $\mathbf{8}$ & $\mathbf{1 0}$ \\
\hline Avicel 101 & $\mathbf{5 5 . 5}$ & $\mathbf{5 5 . 5}$ & $\mathbf{5 5 . 5}$ & $\mathbf{5 5 . 5}$ & $\mathbf{5 5 . 5}$ & $\mathbf{5 5 . 5}$ & $\mathbf{5 5 . 5}$ & $\mathbf{5 5 . 5}$ & $\mathbf{5 5 . 5}$ \\
\hline Magnesium Stearate & $\mathbf{3}$ & $\mathbf{3}$ & $\mathbf{3}$ & $\mathbf{3}$ & $\mathbf{3}$ & $\mathbf{3}$ & $\mathbf{3}$ & $\mathbf{3}$ & $\mathbf{3}$ \\
\hline Talc & $\mathbf{3}$ & $\mathbf{3}$ & $\mathbf{3}$ & $\mathbf{3}$ & $\mathbf{3}$ & $\mathbf{3}$ & $\mathbf{3}$ & $\mathbf{3}$ & $\mathbf{3}$ \\
\hline Orange flavor & $\mathbf{1}$ & $\mathbf{1}$ & $\mathbf{1}$ & $\mathbf{1}$ & $\mathbf{1}$ & $\mathbf{1}$ & $\mathbf{1}$ & $\mathbf{1}$ & $\mathbf{1}$ \\
\hline Aspartame & $\mathbf{2}$ & $\mathbf{2}$ & $\mathbf{2}$ & $\mathbf{2}$ & $\mathbf{2}$ & $\mathbf{2}$ & $\mathbf{2}$ & $\mathbf{2}$ & $\mathbf{2}$ \\
\hline Mannitol & $\mathbf{Q S}$ & $\mathbf{Q S}$ & $\mathbf{Q S}$ & $\mathbf{Q S}$ & $\mathbf{Q S}$ & $\mathbf{Q S}$ & $\mathbf{Q S}$ & $\mathbf{Q S}$ & $\mathbf{Q S}$ \\
\hline Total weight & $\mathbf{1 5 0}$ & $\mathbf{1 5 0}$ & $\mathbf{1 5 0}$ & $\mathbf{1 5 0}$ & $\mathbf{1 5 0}$ & $\mathbf{1 5 0}$ & $\mathbf{1 5 0}$ & $\mathbf{1 5 0}$ & $\mathbf{1 5 0}$ \\
\hline
\end{tabular}

\section{Evaluation of oral fast disintegrating tablets}

a) Weight variation: Average weight of 20 tablets were selected randomly from the lot and weighed individually to check for weight variation.

b) Tablet Thickness: Ten tablets were taken and their thickness was recorded using Vanier calliper. It is measured in $\mathrm{mm}$

c) Tablet Hardness: Hardness of the tablet of each formulation was determined using Monsatoo hardness tester.

d) Friability (F): Friability of the tablet is determined using Roche friabilator. This device subjects the tablet to the combined effect of abrasion and shock in a plastic chamber revolving at $25 \mathrm{rpm}$ and dropping a tablet at a height of 6 inches in each revolution. Pre weighed sample of tablets was placed in the friabilator and were subjected to the 100 revolutions. Tablets were dusted using a soft muslin cloth and reweighed. The friability $(\mathrm{F})$ is given by the formula.

\section{$\%$ Friability $=$ loss in weight $/$ Initial weight $x 100$}

e) Wetting Time: The wetting time of the tablets can be measured using a simple procedure. Twice folded circular tissue papers of $10 \mathrm{~cm}$ diameter were placed in a Petridis with a $10 \mathrm{~cm}$ diameter. $10 \mathrm{ml}$ of $\mathrm{pH} 6.8$ phosphate buffer. A tablet is carefully placed on the surface of the tissue paper. The time required for phosphate buffer to reach upper surface of the tablet is noted as a wetting time.

f)Water Absorption Ratio: A piece of tissue paper folded twice was placed in a small Petri dish containing $6 \mathrm{ml}$ of pH 6.8 phosphate buffer. A tablet was put on the tissue paper and allowed to completely wet. The wetted tablet was then weighed. Water absorption ratio, $\mathrm{R}$ was determined using following equation.

\section{$\mathrm{R}=100 \times(\mathrm{Wa}-\mathrm{Wb}) / \mathrm{Wa}$}

Where, $\mathrm{Wa}=$ Weight of tablet after water absorption

$\mathrm{Wb}=$ Weight of tablet before water absorption. g) In vitro dispersion time: In vitro dispersion time was measured by dropping a tablet in a $10 \mathrm{ml}$ measuring cylinder containing $6 \mathrm{ml}$ of buffer solution simulating saliva fluid ( $\mathrm{pH} 6.8)$ at $37 \pm 0.5^{\circ} \mathrm{C}$ and the time required for complete dispersion was determined.

h) Content Uniformity: The content uniformity of the prepared formulas orodispersible tablets was performed by taking ten tablets and assayed individually. The requirement for this test is met if the amount of ingredient in each of the ten tablets lies within the range of $95 \%-102 \%$.Taken five tablets were powered and the blend equivalent to $20 \mathrm{mg}$ of Ondansetron was weight and dissolved in $100 \mathrm{ml}$ of phosphate buffer ( $\mathrm{pH} \mathrm{6.8)}$. Stock solutions are sonicted for 14 minute. Filter the sample and withdraw $1 \mathrm{ml}$ filtrate was taken in $25 \mathrm{ml}$ phosphate buffer $(\mathrm{pH}$ 6.8) and analyzed spectrophotometrically at $310 \mathrm{~nm}$. The amount of Ondansetron was estimated by using standard calibration curve of drug

\section{RESULT AND DISCUSSION}

\section{Identification and Characterisation of Ondansetron $\mathrm{HCl}$}

\section{Melting Point}

The melting point of the Ondansetron $\mathrm{HCl}$ was found to be $231^{\circ} \mathrm{C}$, which complies with $\mathrm{BP}$.

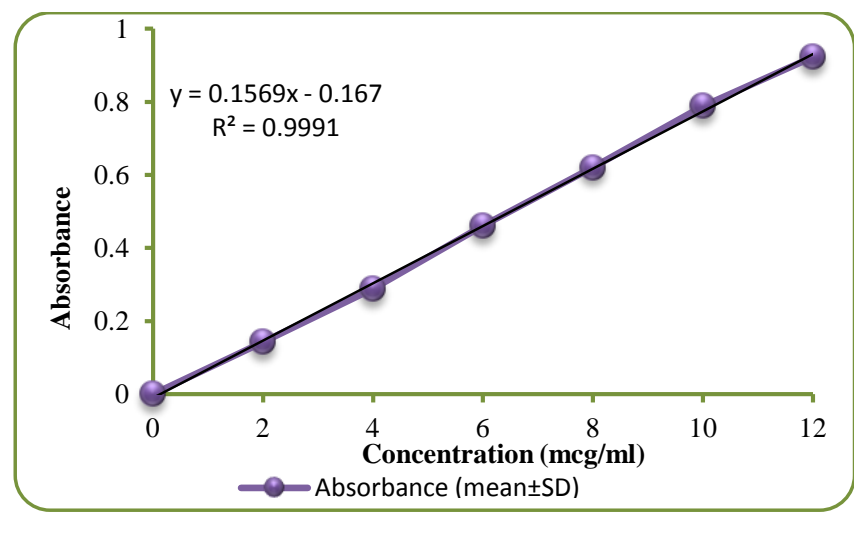

Standard calibration curve of Ondansetron $\mathrm{HCl}$ 


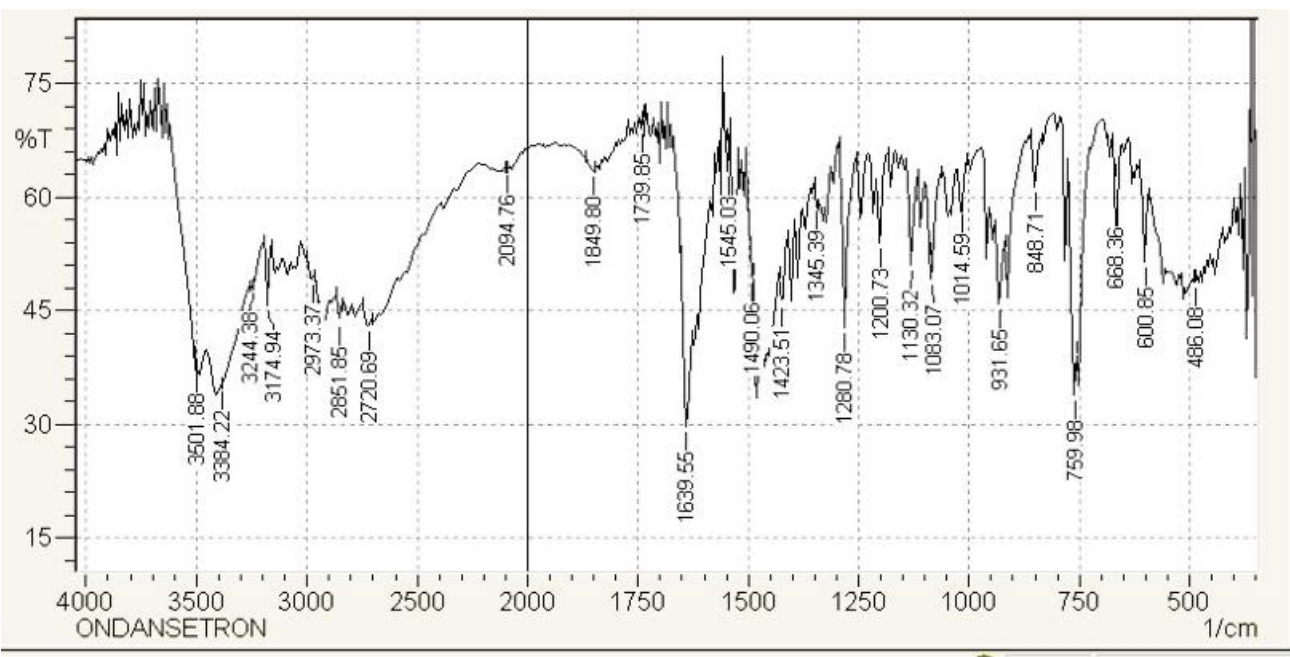

Figure 1: FTIR spectrum of Ondansetron HCL

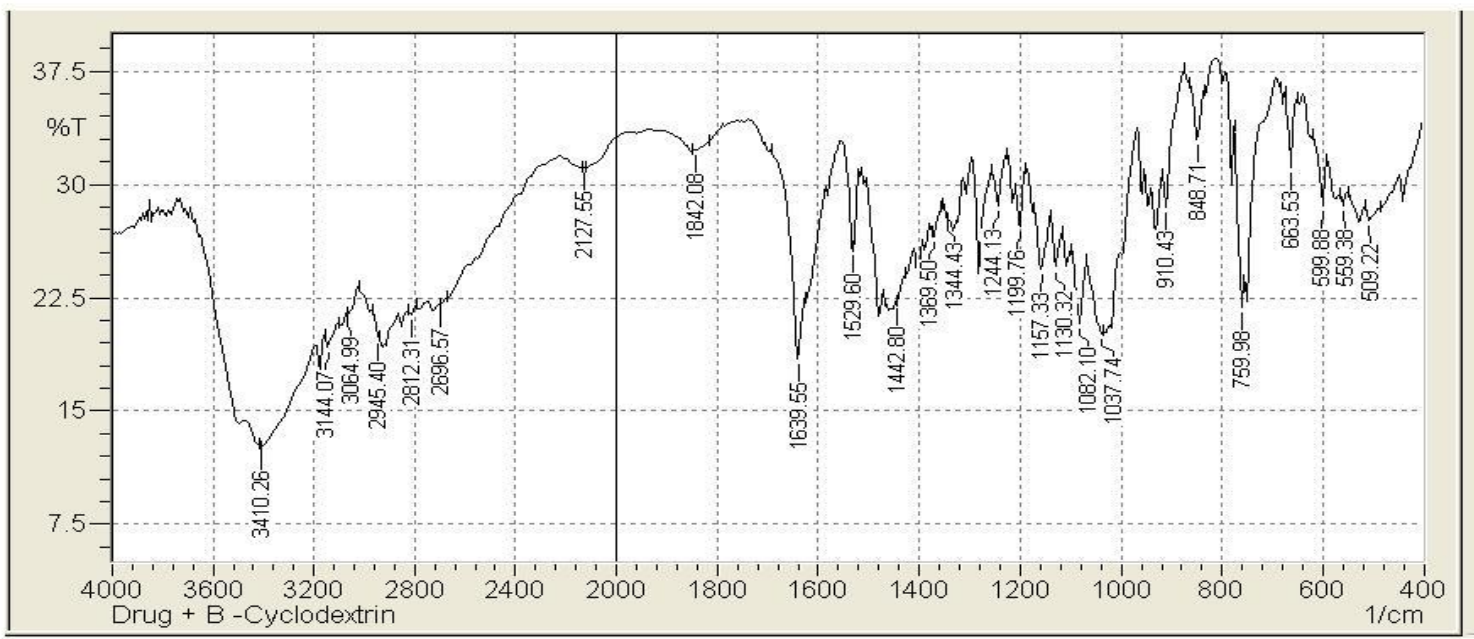

Figure 2: FTIR spectrum of Ondansetron HCL with cyclodextrin complex

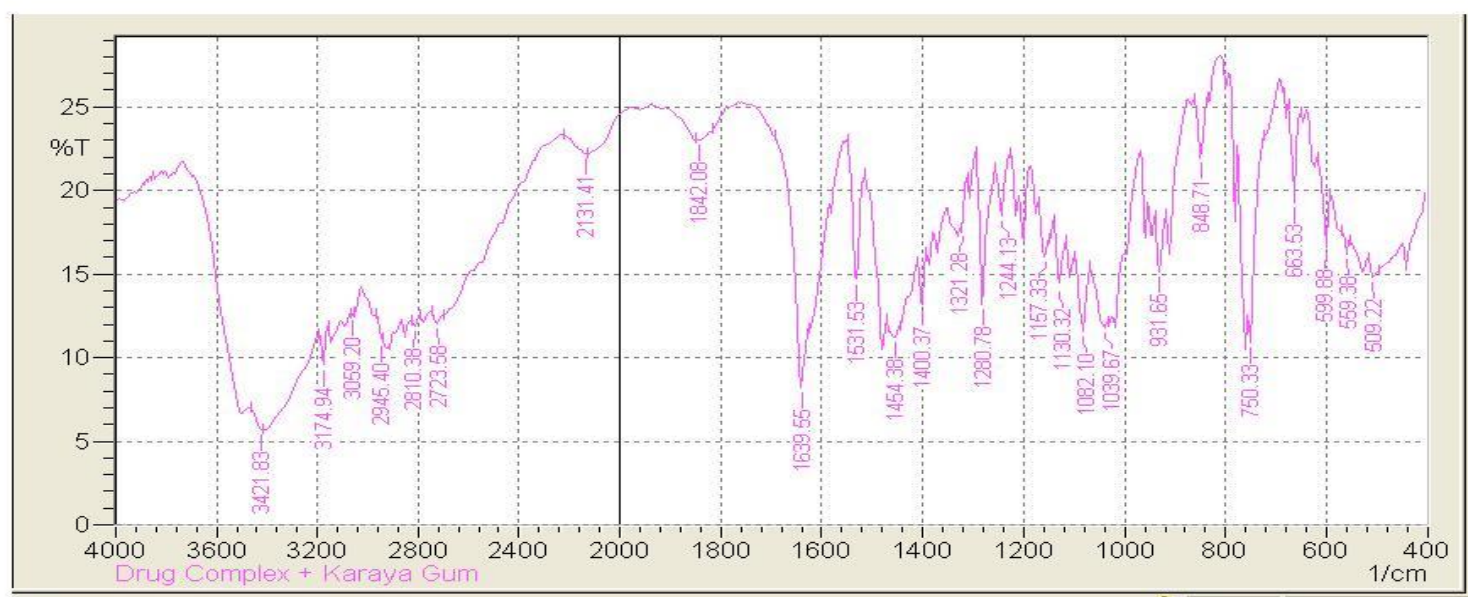

Figure 3: FTIR spectrum of Ondansetron HCL in powder blend

From FTIR study it can concluded that the drug Ondensetron HCL have maintained its identity without losing its characteristic properties. 


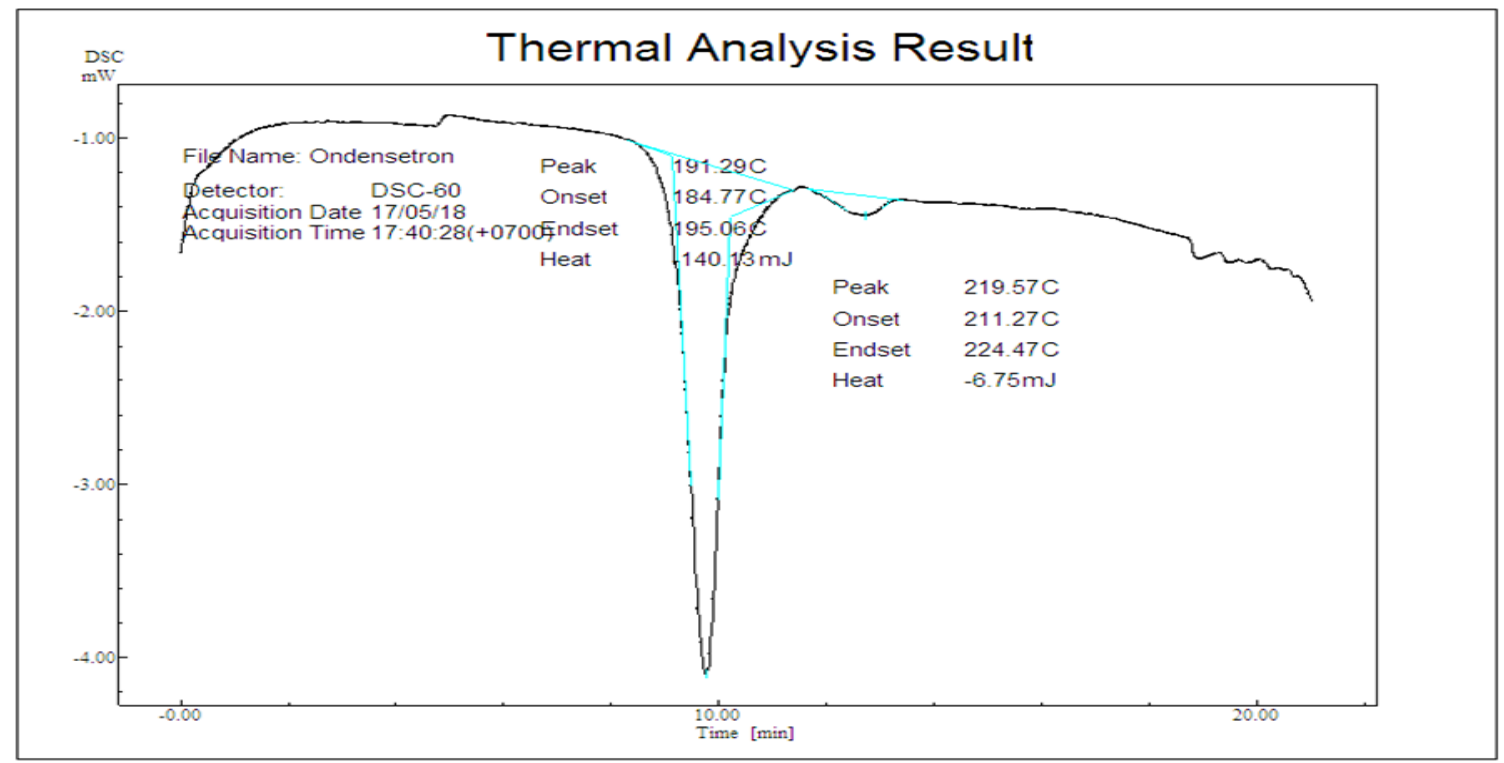

Figure 4: Differential Scanning Calorimetry of Ondansetron $\mathrm{HCl}$

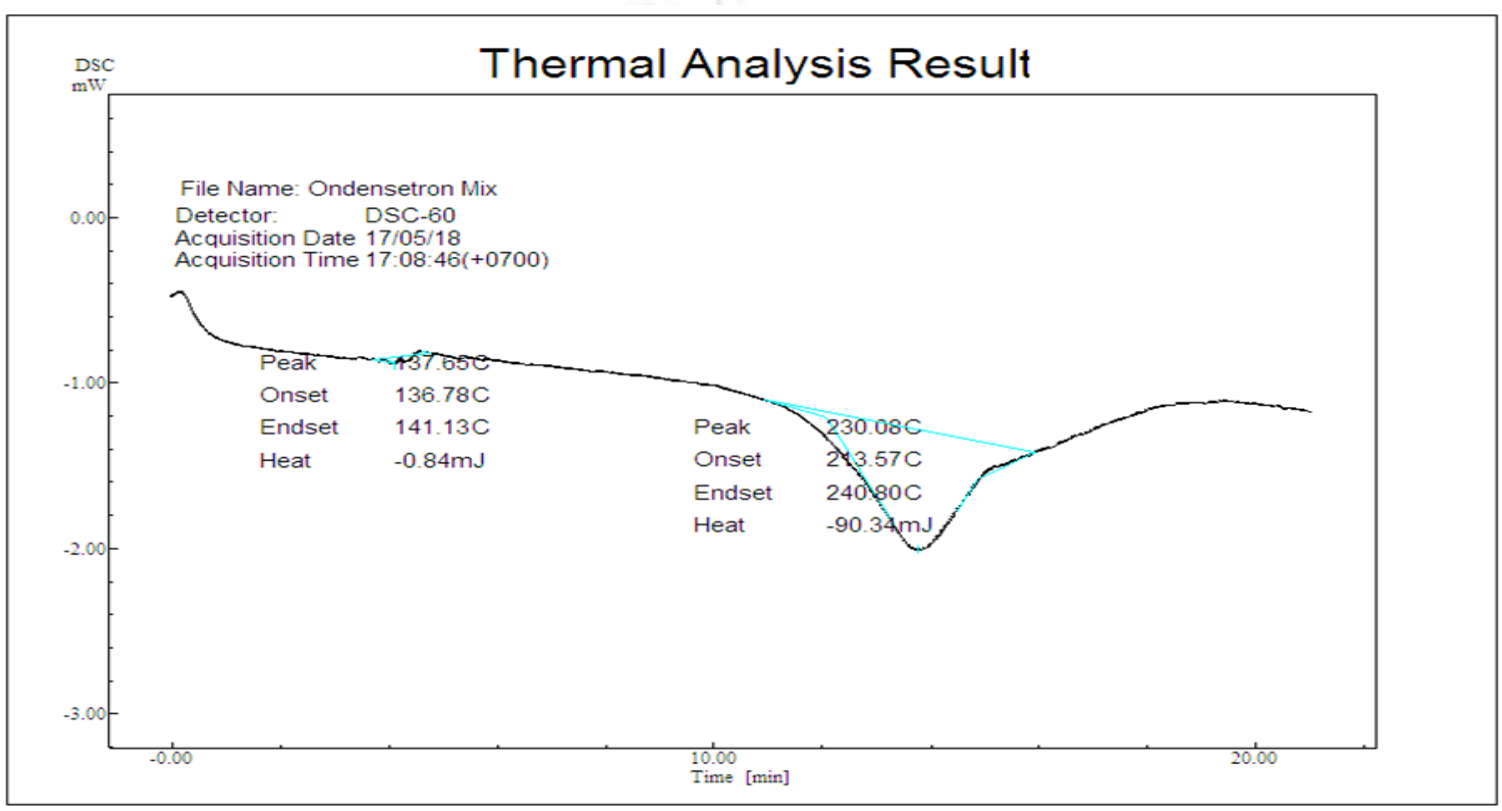

Figure 5: Differential Scanning Calorimetry of Ondansetron $\mathrm{HCl}$ with Excipients

The DSC thermogram of Ondencetron Fig.4 and Losartan Potassium Fig.5 exhibited a single sharp endothermic peak at $230^{\circ} \mathrm{C}$ respectively, related to its melting transition temperature.

Table 2: Post-compression parameter of batches F1-F9

\begin{tabular}{|c|c|c|c|c|}
\hline Formulation & $\begin{array}{c}\text { Thickness } \mathbf{( n = 3 )} \\
(\mathbf{m m})(\mathbf{S D})\end{array}$ & $\begin{array}{c}\text { Hardness } \\
\left(\mathbf{k g} / \mathbf{c m}^{\mathbf{2}}\right)(\mathbf{n = 3})(\mathbf{S D})\end{array}$ & $\begin{array}{c}\text { Friability } \\
(\mathbf{\%})\end{array}$ & $\begin{array}{c}\text { Weight Variation } \\
(\mathbf{n = 2 0})(\mathbf{m g})(\mathbf{S D})\end{array}$ \\
\hline F1 & $2.49 \pm 0.2$ & $3.13 \pm 0.04$ & 0.81 & Passable \\
\hline F2 & $2.95 \pm 0.1$ & $2.99 \pm 0.04$ & 0.45 & Passable \\
\hline F3 & $2.43 \pm 0.3$ & $3.02 \pm 0.06$ & 0.71 & Passable \\
\hline F4 & $2.58 \pm 0.2$ & $3.04 \pm 0.31$ & 0.64 & Passable \\
\hline F5 & $2.56 \pm 0.2$ & $2.84 \pm 0.04$ & 0.56 & Passable \\
\hline F6 & $3.03 \pm 0.3$ & $3.45 \pm 0.09$ & 0.80 & Passable \\
\hline F7 & $3.02 \pm 0.3$ & $2.90 \pm 0.02$ & 0.33 & Passable \\
\hline F8 & $3.06 \pm 0.2$ & $3.00 \pm 0.02$ & 0.66 & Passable \\
\hline
\end{tabular}


Table 3: Other Post-Compression parameters of batches F1-F9

\begin{tabular}{|c|c|c|c|}
\hline Formulation & Wetting time (Sec) & Water absorption Ratio (SD) & Dispersion Time (sec) (SD) \\
\hline F1 & 44 & $53 \pm 0.2$ & $33 \pm 0.2$ \\
\hline F2 & 36 & $55 \pm 0.1$ & $34 \pm 0.3$ \\
\hline F3 & 39 & $64 \pm 0.5$ & $34 \pm 0.2$ \\
\hline F4 & 42 & $62 \pm 0.2$ & $43 \pm 0.5$ \\
\hline F5 & 49 & $54 \pm 0.2$ & $50 \pm 0.4$ \\
\hline F7 & 43 & $63 \pm 0.6$ & $46 \pm 0.2$ \\
\hline F8 & 38 & $53 \pm 0.1$ & $33 \pm 0.4$ \\
\hline F9 & 35 & $62 \pm 0.4$ & $32 \pm 0.4$ \\
\hline
\end{tabular}

In vitro Dissolution study of formulation batches F1-F9

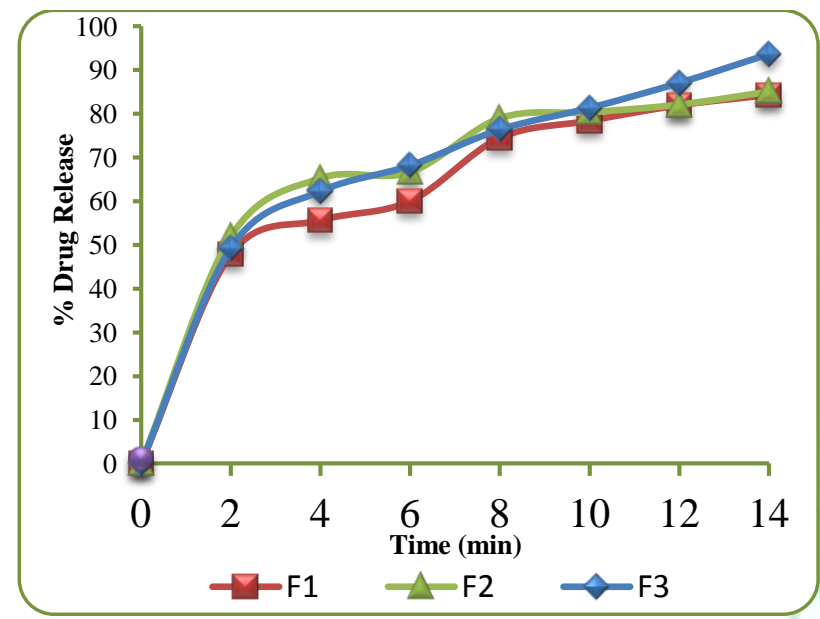

Figure 6: Comparative in vitro release profile of Ondansetron $\mathrm{HCl}$ Fast disintegrating tablets for formulation F1to F3

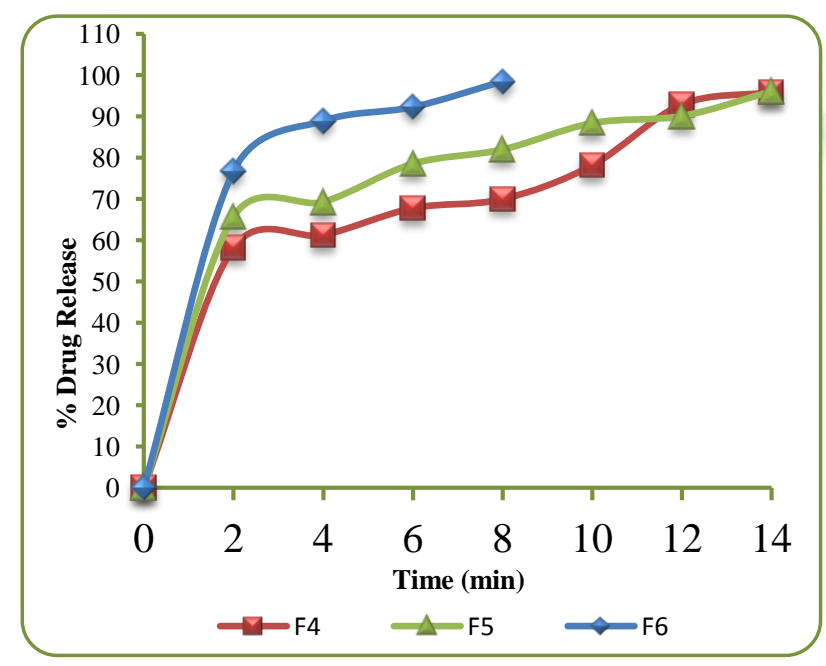

Figure 7: Comparative in vitro release profile of Ondansetron $\mathrm{HCl}$ Fast disintegrating tablets for formulation F4 to F6.

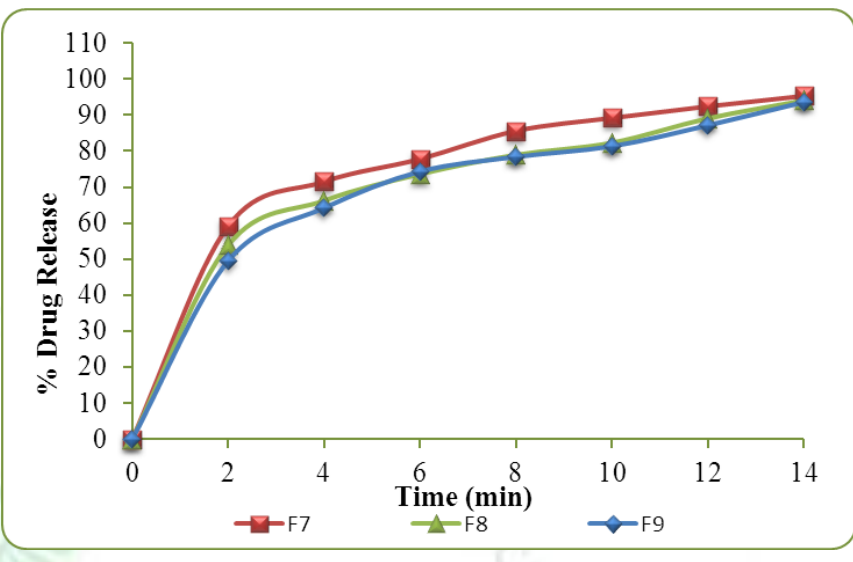

Figure 8: Comparative in vitro release profile of Ondansetron $\mathrm{HCl}$ Fast disintegrating tablets for formulation F7 to F9

\section{CONCLUSION}

The Fast disintegrating tablets of Ondansetron $\mathrm{HCl}$ were prepared by direct compression method using different superdisintegrant such as Crospovidone, Karaya gum and Fenugreek gum in different concentration with help of ball mill for coprocessing. The mannitol was stick to dies and punch therefore ball mill is use to prepare coground mixtures of crospovidone and mannitol to improve the compatibility and stability of product. The FTIR, DSC analysis revealed that the Betacyclodextrin and polymer used were compatible with Ondansetron $\mathrm{HCl}$. Disintegration time decrease with increase in the concentration of superdisintegrant. Among all formulation, containing Karaya Gum as superdisintegrants is fulfilling all the parameters satisfactorily. In vitro release studies that almost $98.88 \%$ of drug was release from all the formulation were within 15 minutes. Formulation F6 showed faster drug release within 7 minutes in comparison to other formulation.Thus result shows that Co-processing of excipients is most suitable approach for formulation of Fast dissolving tablet. 


\section{REFERENCES}

1. Tomar M, Sinha AR, Singh AK, Process and Development of Co-Processed Excipient Silicified Microcrystalline Cellulose and Manufacture Paracetamol Tablet by Direct Compression. Int. J. Pharm. Sci. Rev. Res., 2017; 42(1):191-196.

2. Nautiyal U, Singh S, Singh R, Gopal, Kakar S, Fast Dissolving Tablets As A Novel Boon: A Review: Journal Of Pharmaceutical, Chemical And Biological sciences May 2014; 2(1):05-26.

3. More S, Ghadge T, Fast Disintegrating Tablets: An Overview Asian J. Res. Pharm. Sci. 2013; 3:47-55.

4. Mali RR, Gupta S, Goel V, Novel Study In Fast Dissolving Drug Delivery System: A Review: Indian Journal Of Pharmaceutical And Biological Research (Ijpbr), 2015; 3(1):93-107.

5. Nautiyal U, Aggarwal P, Mali RR, A Review On: Fast Dissolving Tablet Int. J Rec. Adv. Sci. Tech, 2015; 2(2):2028.

6. Marwaha M, Sandhu D, Marwaha RK. Coprocessing of excipients: a review on excipient development for improved tabletting performance, International Journal of Applied Pharmaceutics, 2010; 2(3):41-42.
7. Shirwaikar AA. Novel coprocessed excipients of Mannitol and microcrystalline cellulose for preparing fast dissolving tablets of glipizide. Indian J Pharm Sci, 2007; 69:633-9.

8. Chougule AS, Dikpati A, Trimbake T. Formulation Development Techniques of Co-processed Excipients. Journal of Advanced Pharmaceutical Sciences, 2012; 2(2):231-249.

9. Chowdary KPR, Franklin Israel $S$ and Satyanarayana AR. Preparation, Characterization and Evaluation of Starch - PEG 1500 Co-Processed Excipient as Directly Compressible Vehicle in Tablet Formulations. International Journal of Comprehensive Pharmacy, 2012; 11(4):1-4.

10. Chowdary KPR and Ramya K. Recent Research on CoProcessed Excipients for Direct Compression-A Review. International Journal of Comprehensive Pharmacy, 2013; 2(01):1-5.

11. Fu Y, Yang S, Jeong SH, Kimura S, Park K, Orally Fast Disintegrating Tablets: Developments, Technologies, TasteMasking and Clinical Studies, Critical Reviews ${ }^{\mathrm{TM}}$ In Therapeutic Drug Carrier Systems, 2004; 21(6):433-475.

12. Kumar S, Kaur H, Mishra PB, Vashisht N, Vimalarora, Mouth Dissolving Tablets: A Convenient Novel Dosage Form - A Review,International Journal of Pharmaceutical Research And Development, 2013; 5(08):021-032. 